\title{
Parental and community outreach: Examining kindergarten's outreach efforts from principals', teachers', and parents' perspectives
}

Merfat Fayez, Department of Child Education, Queen Rania Faculty for Childhood, The Hashemite University, Zarqa, Jordan, mfayez@hu.edu.jo

\begin{abstract}
The current study was conducted to examine Jordanian kindergartens' outreach efforts from principals', teachers', and parents' views. Study samples consisted of 131 kindergarten teachers and principals and 205 parents of kindergarten children. Study samples were drawn randomly from Zarqa city, Jordan. To achieve the study goals, two questionnaires were developed. The first questionnaire measured kindergarten principals' and teachers' views about the degree of implementation of different aspects of parent involvement, while the second one measured parents' views about their children's kindergarten outreach efforts. Study results were analyzed using descriptive statistics. Findings showed that many aspects of parent involvement within the varied levels of involvement in Epstein's model were implemented to a high degree and that other aspects were overlooked based on the views of participants. The study concludes by presenting many recommendations and suggestions based on the findings of this study.
\end{abstract}

Keywords: Parent involvement, Home-school partnership, Involvement outreach efforts

Received: 04.12.2020 $\quad$ Accepted: 14.01.2021 $\quad$ Published: 05.02.2021

\section{INTRODUCTION}

Research studies have shown that parent involvement provide parents, teachers, and students with many benefits. For example, children of highly involved parents have elevated achievement scores (Lin, 2003; Nye et al., 2006), better attendance, increased motivation and self-esteem, better social adjustment and lower rates of antisocial and violent behaviors (Al-Rawwad et al., 2016; El Nokali et al., 2010; Fantuzzo, McWayne, et al., 2004; Fantuzzo, Tiigh, et al., 2003; McWayne et al., 2004). From a different angle, schools and parents can also harvest the benefits of parent involvement. Schools that actively involve parents and the community tend to gain higher levels of parental and community support and lead more successful and effective programs (Olsen \& Fuller, 2008). Besides, parents who are active participants in the education of their children tend to quickly respond to the social, emotional, and learning needs of their children and form better relationships with them (Al-Hassan \& Lansford, 2011).

The concept of parent involvement developed over the years due to extensive research studies. Basically, it has been defined through the involvement practices that are enacted from home and the more visible forms enacted through participating in school activities (Hoover-Dempsey \& Sandler,1997). The broader community in which the child lives was also considered a crucial partner alongside the home and the school (Chrispeels, 1996). This in turn points to the multifaceted nature of the concept which needs to be considered when it is studied.

In the last decades, Jordan went through many renovations in its educational system. As part of this educational renovation, the Jordanian Ministry of Education (MoE) has revamped its educational system under the Education Reform for the Knowledge Economy Project (ERfKE) 2003/2008 (Kaga, 2007). One action area that was given considerable attention is parental engagement (Kaga, 2007). To achieve that, the MoE in partnership with UNICEF's Jordan office started the Better Parenting initiative in some of the public kindergartens to empower parents and increase their awareness of their roles in the education of their children (Sultana, 2009).

The development of programs that purposefully target kindergarten parents' engagement is widely acknowledged to increase the level of involvement among parents (e.g., Brown et al., 2014). Yet, the Better Parenting Project was characterized to be founded on the deficits view of parents (Sultana, 2009). Furthermore, it focused on the basic levels of involvement by empowering parents to provide stimulating home environment and overlooked other levels of parent involvement such as decision making and volunteering. 
There is a constant need to assess the types and forms of involvement enacted in Jordanian kindergartens in light of these governmental efforts. Therefore, this study intends to examine Jordanian kindergartens' efforts in involving parents and community from principals', teachers', and parents' perspectives. The study is using the parent involvement model of Epstein as a benchmark from which to measure outreach efforts of Jordanian kindergartens. The specific research queries are:

1. How do kindergarten principals and teachers view parental and community outreach efforts?

2. How do parents of kindergarten children view parental and community outreach efforts?

\section{Conceptual framework}

Despite the positive outcomes of parent involvement, parents may choose to participate in their children's education on a minimum level. Many factors may play a role in parents' decisions of involvement. In an extensive review conducted by Hoover-Dempsey and Sandler (1997) to understand the barriers that may hinder parents from participating in their children's education, they classified the perceptions of parents toward involvement into three groups. These are: the motivational beliefs, parents' life-context variables, and parents' perceptions of whether schools are welcoming and inviting or not.

The perceptions of parents toward school's invitation efforts have been identified as a key factor in parental decisions. Research studies (e.g., Murray et al., 2014) found a link between the motivational factors including invitation for involvement and the type and frequency of parental engagement applied. Similar findings were reported by Lewis and Forman (2002) who found that the classroom environment which was convivial, warm, and inviting contributed to the active participation of parents.

In a study conducted by Fayez et al. (2011), it was found that there was a significant association between how parents perceive the efforts exerted by the schools to involve them and the involvement roles enacted by parents at home and at school. In another study conducted by Frew (2012), it was found that parent involvement improved in schools which provided more outreach activities. Schools and teachers, therefore, play a decisive role in facilitating parental decisions to participate in their children's education (Anderson \& Minke, 2007; Overstreet et al., 2005; Patrikakou \& Weissberg, 1998).

In addition to the motivational aspect of parent involvement, the schools may also be blamed for setting traditional school involvement opportunities that do not empower parents to elevate their involvement to higher levels and forms as suggested by Joyce Epstein (1995). Upon the recognition of the importance of parent involvement, Epstein presented an ample model to assess parent involvement. In her model, she presented six different levels that capture the wide array of involvement roles enacted by parents, schools, and the community. These levels are:

1. parenting which refers to the endorsement of parents to their essential parenting roles through providing basic needs to their children,

2. communicating which refers to the two-way communications between school and parents

3. volunteering which refers to parents taking part in school-related gatherings, conferences and activities,

4. learning at home which refers to the support given to students by their family members in relation to the educational and academic needs,

5. decision making which refers to parental participation in shaping the policies and regulations of the school and participating in decision-making teams, and finally

6. forming partnership with the community which refers to the support given to schools by the community (Epstein \& Jansorn, 2004; Epstein \& Salinas, 2004).

Each level described in Epstein's model represent a range of possible roles that can be commenced by either parents or the schools to improve parental engagement (Casanova, 1996). It may also work as guidelines to encourage more informed decisions about how best to extend parental participation through deliberate parental involvement programs (Gianzero, 1999). These types were endorsed within the standards of the National Parent-Teacher Association (PTA) (Trotti et al., 2006).

Hence, when schools exert more effort in involving parents, parents are expected to become more active and would want to increase their level of involvement. For example, Lewis and Forman (2002) have found that parents became more active regarding school policies that affect their children's education when they were requested by the school to be part of the decision-making team.

It is widely acknowledged that when schools offer parents and communities the opportunities to get involved at higher levels of involvement, they are more likely to be empowered to act on these roles. This could only happen if schools move away from the traditional view of the concept of parent involvement that blame parents and help parents increase their involvement roles by offering them with varied opportunities to become involved (Jordan et al., 2002). In light of the importance of the schools' role, it becomes very important to examine kindergarten parental involvement and outreach efforts. 
Therefore, this study intends to examine the parental involvement outreach efforts of kindergartens in Jordan.

Knowledge obtained in this research is expected to help policymakers gain specific and detailed information about the strength and weakness points in the outreach efforts of Jordanian kindergartens in relation to Epstein's model and therefore, devise particular mechanisms to enhance these efforts. Furthermore, the information obtained in this study is expected to add to the international literature about parent involvement in general and, more specifically, to the growing literature about parent and community involvement in the Jordanian context.

\section{METHODS}

This study implemented a quantitative methodology as data were collected through two questionnaires and were analyzed quantitatively. The questionnaires included items to measure how Jordanian kindergarten principals, teachers, and parents examine the efforts exerted by kindergartens in Jordan to involve parents using the parental involvement model of Epstein as a benchmark.

\section{Data Collection and Procedures}

Two questionnaires were developed by the researcher after examining the literature that pertains to using Epstein's model of involvement in assessing the involvement practices offered by schools and kindergartens. The first questionnaire was developed to measure kindergarten principals' and teachers' perspectives about the degree of implementation of different aspects of parent involvement as described by Epstein's model, in addition to measuring their views about the importance of these aspects.

The principal and teacher questionnaire included two sections. The first section collected information about participants' demographics, such as their number of years of experience and their qualification, whereas the second section included 31 items that clustered around the six levels of involvement suggested by Epstein. These levels are: parenting, communicating, volunteering, learning at home, decision making, and collaborating with the community (Epstein, 1995). We asked teachers and principals first to rate the importance of each aspect described by every item. Principals and teachers rating of importance was measured on a dichotomous scale (important, not important) that was scored $(1,0)$ respectively. Then they were asked about the degree they felt their kindergarten apply that aspect of involvement on a four-level Likert scale ranging from (not applied at all, applied to a low degree, applied to a moderate degree, and applied to a high degree). The respective scores for each quality ranged from $(0-3)$.

The parent questionnaire was developed to measure the views of parents about the degree of kindergartens' implementation of different aspects of parental engagement as described by Epstein's model. The questionnaire included two sections, one collected demographic information about parents, while the other one included (21) items that were set on a four-level Likert scale ranging from (not applied at all, applied to a low degree, applied to a moderate degree, and applied to a high degree). The respective scores for each quality ranged from $(0-3)$.

\section{Study Samples}

The samples for this study were drawn from two populations. The first sample consisted of 131 kindergarten teachers and principals. In terms of experience, $46.1 \%$ of the participants in this sample had less than 5 years of experience, while $30.5 \%$ of them had from 5-10 years of experience and $23.4 \%$ had more than ten years of experience. As to their qualifications, $52.8 \%$ of the participants had a diploma, while $39.4 \%$ of them had a bachelor's degree and only $7.1 \%$ had a graduate degree.

The second sample consisted of 205 parents of kindergarten children, $41 \%$ of whom have a secondary certificate, $24.8 \%$ have a diploma, and $31.7 \%$ have an undergraduate degree. Both samples were selected randomly from Zarqa city; a highly populated city in Jordan.

\section{RESULTS}

\section{Results of the First Research Query}

The first research question in this study aims to explore how both principals and teachers assess their kindergartens' efforts in empowering aspects of parent involvement that relate to Epstein's framework and their views of the importance of these aspects.

To answer this question, data were analyzed by the SPSS program through calculating the means and standard deviations for the 31 items of the questionnaire. Two means were obtained for each item; one for participants' views on the importance of the parent involvement aspect (referred to as mean of 
importance hereinafter), and the second for participants' assessment of the extent to which this aspect is being applied by the kindergarten (referred to as mean of application hereinafter). The following table presents the results of the 31 questionnaire items.

Table 1. Means and std. deviations for principals' and teachers' views of outreach efforts

\begin{tabular}{|c|c|c|c|c|c|}
\hline \multirow[b]{2}{*}{ Number } & \multirow[b]{2}{*}{ items } & \multicolumn{2}{|c|}{ Application } & \multicolumn{2}{|c|}{ Importance } \\
\hline & & Means & $\begin{array}{l}\text { Std. } \\
\text { Deviations }\end{array}$ & Means & $\begin{array}{l}\text { Std. } \\
\text { Deviations }\end{array}$ \\
\hline 1. & $\begin{array}{l}\text { Conducts workshops or sends emails to } \\
\text { parents with information about how } \\
\text { children develop and learn }\end{array}$ & 1.6423 & 1.07223 & .8870 & .31803 \\
\hline 2. & $\begin{array}{l}\text { Conducts workshop or sends emails with } \\
\text { information about the positive parenting } \\
\text { styles and practices }\end{array}$ & 1.6083 & 1.11744 & .8661 & .34211 \\
\hline 3. & $\begin{array}{l}\text { Develops family support program which } \\
\text { provides health, nutritious or other } \\
\text { services }\end{array}$ & 1.5040 & 1.14035 & .7545 & .49189 \\
\hline 4. & $\begin{array}{l}\text { Implements home visits to ease the } \\
\text { transition of children to kindergartens }\end{array}$ & 1.2689 & 1.23986 & .6168 & .48845 \\
\hline 5. & $\begin{array}{l}\text { Conducts meetings with the neighborhood } \\
\text { and local community to understand their } \\
\text { needs and convey the kindergarten's } \\
\text { mission }\end{array}$ & 1.1176 & 1.13628 & .5575 & .49889 \\
\hline 6. & $\begin{array}{l}\text { Provides parents with suggestions about } \\
\text { best home conditions that help } \\
\text { kindergarten children learn and develop }\end{array}$ & 1.9831 & .98695 & .8661 & .34211 \\
\hline 7. & $\begin{array}{l}\text { Arranges for a parent-teacher conference } \\
\text { during the year }\end{array}$ & 2.2231 & .86108 & .9167 & .27754 \\
\hline 8. & $\begin{array}{l}\text { Provides parents with clear information } \\
\text { about the kindergarten policy and } \\
\text { regulations }\end{array}$ & 2.5000 & .83011 & .9322 & .33915 \\
\hline 9. & $\begin{array}{l}\text { Sends children's portfolios weekly or } \\
\text { monthly for parents to view and comment }\end{array}$ & 2.4370 & .95348 & .8803 & .32596 \\
\hline 10. & $\begin{array}{l}\text { Makes arrangements and schedules for } \\
\text { parents to receive their children's report } \\
\text { cards }\end{array}$ & 2.5041 & .84778 & .9397 & .23916 \\
\hline 11. & $\begin{array}{l}\text { Develops a specific regular schedule for } \\
\text { communication with parents through } \\
\text { written notes, weekly newsletters, emails, } \\
\text { phone calls... }\end{array}$ & 2.2177 & .94189 & .9145 & .28078 \\
\hline 12. & $\begin{array}{l}\text { Provides parents with information about all } \\
\text { regular kindergarten's activities and } \\
\text { meeting }\end{array}$ & 2.4628 & .90408 & .9068 & .29198 \\
\hline 13. & $\begin{array}{l}\text { Sets a planned schedule for parents to } \\
\text { volunteer in kindergarten's activities. }\end{array}$ & 1.5128 & 1.08767 & .7368 & .44229 \\
\hline 14. & $\begin{array}{l}\text { Sets a schedule for parents to volunteer in } \\
\text { their children's classrooms }\end{array}$ & 1.2222 & 1.10727 & .5565 & .49897 \\
\hline 15. & $\begin{array}{l}\begin{array}{l}\text { Devises a specific room for volunteer } \\
\text { meetings }\end{array} \\
\end{array}$ & 1.3719 & 1.14114 & .6789 & .46906 \\
\hline 16. & $\begin{array}{l}\text { Sends a yearly questionnaire to know } \\
\text { parental and community skills with dates } \\
\text { for volunteering and times appropriate for } \\
\text { volunteering }\end{array}$ & 1.0574 & 1.10071 & .4486 & .49969 \\
\hline 17. & $\begin{array}{l}\text { Implements a clear program to follow up on } \\
\text { communication with parents who wish to } \\
\text { volunteer }\end{array}$ & 1.2066 & 1.14686 & .5780 & .49616 \\
\hline 18. & Provides parents with information about & 2.3770 & .93001 & .9407 & .23723 \\
\hline
\end{tabular}




\begin{tabular}{|c|c|c|c|c|c|}
\hline & $\begin{array}{l}\text { the skills that their child should master in } \\
\text { all academic fields }\end{array}$ & & & & \\
\hline 19. & $\begin{array}{l}\text { Provides parents with information about } \\
\text { the homework policies and how parents } \\
\text { should follow their child }\end{array}$ & 2.2975 & 1.02992 & .8898 & .31444 \\
\hline 20. & $\begin{array}{l}\text { Sets a schedule for homework that is } \\
\text { interactive between parents and their child }\end{array}$ & 2.2295 & 1.03482 & .8522 & .35648 \\
\hline 21. & $\begin{array}{l}\text { Provides suggestions } \\
\text { for learning activities that parents can do } \\
\text { during summer break }\end{array}$ & 1.5902 & 1.21120 & .7788 & .41693 \\
\hline 22. & $\begin{array}{l}\text { Provides suggestions for extra learning } \\
\text { activities that parents can do with their } \\
\text { child at home }\end{array}$ & 1.9915 & 1.08994 & .8889 & .31562 \\
\hline 23. & $\begin{array}{l}\text { Involves parents through active schools' } \\
\text { board and other ways to represent other } \\
\text { parents }\end{array}$ & 1.7966 & 1.05862 & .8908 & .31326 \\
\hline 24. & $\begin{array}{l}\text { Encourages parents to provide suggestions } \\
\text { to improve and develop the kindergarten }\end{array}$ & 1.7414 & 1.15058 & .8103 & .39373 \\
\hline 25. & $\begin{array}{l}\text { Encourages parents to be involved in } \\
\text { decision making }\end{array}$ & 1.4530 & 1.14843 & .6667 & .47349 \\
\hline 26. & $\begin{array}{l}\text { Provides parents with information on how } \\
\text { to be involved in school boards }\end{array}$ & 1.6638 & 1.20826 & .7652 & .42572 \\
\hline 27. & $\begin{array}{l}\text { Creates a network of communication } \\
\text { between school boards representatives and } \\
\text { other parents }\end{array}$ & 1.5714 & 1.19015 & .7788 & .41693 \\
\hline 28. & $\begin{array}{l}\text { Provides children and parents with } \\
\text { information about health, social, cultural } \\
\text { events presented by the local community }\end{array}$ & 1.6500 & 1.09736 & .8018 & .40045 \\
\hline 29. & $\begin{array}{l}\text { Forms partnerships with other } \\
\text { kindergartens and academic institutions }\end{array}$ & 1.1695 & 1.10403 & .5905 & .49410 \\
\hline 30. & $\begin{array}{l}\text { Provides services to the local community } \\
\text { like artistic activities, recycling.... }\end{array}$ & 1.6271 & 1.16792 & .8073 & .39621 \\
\hline 31. & $\begin{array}{l}\text { Provides parents with information about } \\
\text { cultural or educational activities conducted } \\
\text { during summer by other institutions in the } \\
\text { community. }\end{array}$ & 1.6356 & 1.23112 & .8468 & .36177 \\
\hline
\end{tabular}

As can be seen from Table 1, item 10 "makes arrangements and schedules for parents to receive their children's report cards" obtained the highest mean score of the application (2.5041) indicating that participants felt that their kindergartens apply this aspect to a high degree. Participants also viewed this item as very important with a mean score of (.9397).

The item that obtained the second highest application mean score was item 8 "provides parents with clear information about the kindergarten's policy and regulations." The mean score of application was (2.5000). This item was also viewed as important by participants ( $M$ importance $=.9322$ ).

On the other hand, item 16 " sends a yearly questionnaire to know parental and community skills with dates for volunteering and times appropriate for volunteering" obtained the least mean score of application (1.0574) indicating that participants perceived this aspect as the least applied form of involvement by their kindergarten. Participants also viewed this aspect as the least important form of involvement as well. The item obtained a low mean score of importance (.4486).

\section{Results of the Second Research Query}

To answer this research question, data were analyzed through calculating the means and standard deviations for the 21 items that measure parents' perceptions of their children's kindergarten efforts to involve them in aspects relevant to Epstein's Model. Table 2 summarizes the descriptive analysis of the data. 
Table 2. Means and std. deviations for parents' views of outreach efforts

\begin{tabular}{|c|c|c|c|}
\hline Number & Item & Mean & $\begin{array}{l}\text { Std. } \\
\text { Deviation }\end{array}$ \\
\hline 1. & $\begin{array}{l}\text { Helps me to understand my child's stage of development and } \\
\text { learning }\end{array}$ & 2.5396 & 63160 \\
\hline 2. & Helps me deal with my child in a positive way & 2.4505 & .71933 \\
\hline 3. & $\begin{array}{l}\text { Provides me with information about the skills that my child needs } \\
\text { to learn the different school subjects }\end{array}$ & 2.5600 & .68465 \\
\hline 4. & $\begin{array}{l}\text { Provides me with clear information about the kindergarten's } \\
\text { policy and regulation }\end{array}$ & 2.5950 & .70957 \\
\hline 5. & Invites me to a parent-teacher conference & 2.1841 & 1.07747 \\
\hline 6. & Provides me with information about my child's academic progress & 2.4328 & .85248 \\
\hline 7. & $\begin{array}{l}\text { Sends me my child's portfolio weekly or monthly to review and } \\
\text { comment on }\end{array}$ & 2.4129 & 1.00181 \\
\hline 8. & $\begin{array}{l}\text { Provides me with information on how to develop my child's } \\
\text { performance }\end{array}$ & 2.2650 & .92686 \\
\hline 9. & $\begin{array}{l}\text { Provides me with information about all regular kindergarten } \\
\text { meetings and activities }\end{array}$ & 2.5871 & .73731 \\
\hline 10. & Sends homework that requires me to discuss it with my child & 2.8911 & .34268 \\
\hline 11. & Communicates with me when my child does something good & 2.1980 & 1.02719 \\
\hline 12. & Communicates with me when my child is having a problem & 2.4000 & .90781 \\
\hline 13. & $\begin{array}{l}\text { Communicates with me in different and convenient ways like } \\
\text { phone calls, emails, written notes... }\end{array}$ & 2.4851 & .88226 \\
\hline 14. & Invites me to volunteer in the kindergarten & 1.2161 & 1.21379 \\
\hline 15. & Invites me to volunteer in the classroom & 1.0754 & 1.20158 \\
\hline 16. & $\begin{array}{l}\text { Sends a questionnaire to know my skills and appropriate time for } \\
\text { me to volunteer }\end{array}$ & 9899 & 1.19215 \\
\hline 17. & $\begin{array}{l}\text { Provides me with suggestions for activities that I can do with my } \\
\text { child during holidays }\end{array}$ & 1.3184 & 1.25623 \\
\hline 18. & Invites me to participate in the school board & 2.0099 & 1.19281 \\
\hline 19. & $\begin{array}{l}\text { Encourages me to offer suggestions that help improve the } \\
\text { kindergarten }\end{array}$ & 1.2741 & 1.21470 \\
\hline 20. & $\begin{array}{l}\text { Provides me with information about educational or cultural } \\
\text { programs offered by the local community institutions during } \\
\text { summer }\end{array}$ & 1.2513 & 1.24202 \\
\hline 21. & $\begin{array}{l}\text { Provides me with information about social, health, cultural } \\
\text { services that other community institutions provide }\end{array}$ & 1.2234 & 1.26203 \\
\hline
\end{tabular}

Based on the information presented by Table 2, the parental involvement aspect that was applied the most by the Jordanian kindergartens according to parents was "sends homework that requires discussion with my child" with a mean score (2.8911), followed by item 4 "provides me with clear information about kindergarten's policy and regulation" with a mean score (2.5950).

Whereas the items that obtained the lowest mean scores according to parents were: "sends a questionnaire to know my skills and appropriate time for me to volunteer" with a mean score of (.9899) followed by "invites me to volunteer in the classroom" with a mean score (1.0754).

\section{DISCUSSION AND CONCLUSIONS}

This study is intended to explore how principals, teachers, and parents view Jordanian kindergartens' efforts in involving parents using the parental involvement model of Epstein as a benchmark. Parental involvement has been associated with students' academic performance (Tokac \& Kocayörük, 2012; Topor et al., 2010) and is identified as a major factor that leads to declines in problem behaviors and improvement in social skills (El Nokali et al., 2010). However, according to Patrikakou and Weissberg (1998), schools are usually held accountable for creating and initiating the home-school relationship. Educators are also required to empower parents to perform different roles through involving them in different aspects. In this study, we have utilized Epstein's model of parent involvement to capture and assess the different aspects of involvement that kindergartens in Jordan are implementing to empower 
parents (Epstein \& Salinas, 2004). Epstein's model has been utilized by different researchers to initiate and assess the school-home relationship and as a guide to the development of effective home-school partnership.

The first research question aimed to explore the perceptions of principals and teachers regarding the degree of application of different involvement aspects presented in Epstein's framework. Study findings indicate that principals and teachers agreed that Jordanian kindergartens are applying varied aspects of involvement that relate to the varied levels and types of parent involvement as presented by Epstein's model. For example, principals and teachers agreed that kindergartens provide parents with clear information about the kindergarten's policy and regulations, send children's portfolios weekly or monthly for parents to view and comment on, and make arrangements and schedules for parents to receive their children's report cards. Participants felt that these aspects of parent involvement are applied to a high degree in Jordanian kindergartens.

The strength and quality of parent involvement have changed dramatically in Jordanian schools in recent years. School reform in Jordan which is based on the wealth of literature that document the benefits of parent involvement have raised more awareness among schools and educators on the importance of parents' roles in education. The spread of Better Parenting programs (Sultana, 2009) might have elevated the degree of application of varied forms and aspects of parent involvement by kindergartens. Study findings suggest that kindergarten principals and teachers also perceived many of these aspects as important which indicates a possibility of change in their beliefs as well as their practices.

However, there are some forms and aspects of parent involvement that are still not applied to a high degree by kindergartens in Jordan based on teachers' and principals" responses. Some of the aspects that participants felt kindergartens in Jordan apply to a low level are: setting a schedule for parents to volunteer in their children's classrooms, implementing a clear program to follow up on communication with parents who wish to volunteer, implementing home visits to ease the transition of children to kindergartens, and conducting meetings with the neighborhood and the local community to understand their needs and convey the kindergarten's mission. This finding indicates that there is still room for improvement and that many aspects of parent involvement needs to be strengthened.

Smith and Sheridan (2019) conducted a meta analysis to investigate the effect of 39 teacher training programs on teachers' parent involvement practices, attitudes and knowledge and found that these programs had a significant positive effects on teachers' outcomes. Therefore, we expect that further teachers' training at the pre-service and the in-service levels would affect teachers' parent engagement practices and attitudes positively.

The second research question aimed at exploring the degree of application of varied aspects of parent involvement from parents' perspectives. Findings suggest that, similar to principals and teachers, parents agreed on some aspects of involvement that are applied by kindergartens in Jordan to a high degree. For example, participants agreed that kindergartens send them homework that require them to discuss with their child, provide them with clear information about the kindergarten's policy and regulation, provide them with information about the skills that their children need to learn in the different school subjects, help them understand their child's stage of development and learning, and help them deal with their children in a positive way.

From a different angle, parents reported that some aspects of parent involvement are still not applied to a high degree, such as inviting them to volunteer in the kindergarten or their children's classrooms, sending questionnaires to know their skills, encouraging them to offer suggestions that help improve the kindergarten, and providing them with information about educational or cultural programs offered by the local community during summer.

Interestingly, parents were similar to teachers and principals in relation to the aspects of parent involvement that they viewed as highly implemented and those that are minimally implemented by kindergartens. For example, providing parents with information about the kindergarten's policy and regulations and sending homework were viewed by both groups of participants as highly applied. Furthermore, there was a consensus by both groups of participants that the volunteering aspect of parent involvement is weakly implemented by kindergartens in Jordan.

Results suggest that kindergartens in Jordan might be unaware of or underestimate the importance of parent volunteerism. Research show that when parents volunteer at school activities, children's show better word recognition skills than children whose parents are not volunteering (DeCusati \& Johnson, 2004). The benefits of parent volunteerism exceed the improvement of academic skill among children to the improvement of school safety (Hamlin \& Li, 2019). However, parents may not know about the varied ways of involvement through which they can support their children unless approached by their children's schools. Therefore, schools must provide parents with volunteering opportunities that employ parental 
skills and are appropriate to parents' schedules (Trotti, et al., 2006). Vidal de Haymes et al. (2019) found that when school devise a specific program for parent volunteerism, parents become more engaged even among low-income immigrant parents. Vidal's et al. findings point out to the importance of devising programs and initiatives to target every aspect and type of involvement to strengthen parental involvement practices and attitudes.

\section{CONCLUSION}

This study has explored the varied aspects and levels of parent involvement that are empowered by kindergartens in Jordan against Epstein's (1995) typology of parent involvement. Frequent and meaningful interactions between home and school are suggested to help all of those involved to reap the benefits of this relationship to its fullest.

Findings suggest many ways that are informative to decision and policymakers which better enhance the area of parent involvement. First, teacher preparation programs can provide courses that specifically influence teachers' beliefs and practices in terms of all aspects and possibilities of involvement. New and effective strategies that help teachers realize the wide capacity and possibilities to empower parents and create effective partnerships with them can always be introduced to teachers. Furthermore, continuous professional development training courses for kindergarten principals might strategically focus on areas of weakness in the school-home relationship. This will help schools improve their plans and practices and shift away from traditional forms of parent involvement to new and research-based ones.

Schools can also devise planned partnership programs that repeatedly develop and assess practices and beliefs of all partners including, principals, parents, teachers, and the community. Epstein's model can also be used as a guide to continually assess the possibility that can be created to form an effective relationship.

Similar future research studies that explore the views of principals, teachers, and parents of kindergarten children in different cities in Jordan are still needed. From a different angle, this research has followed the quantitative approach in its design, data collection, and analysis. Therefore, examining the views of principals, teachers, and parents regarding parent involvement through following the qualitative methodology is expected to provide in-depth information and insight to parent involvement research and practice.

\section{REFERENCES}

Al-Hassan, S. M., \& Lansford, J. E. (2011). Evaluation of the better parenting programme in Jordan. Early child development and care, 181(5), 587-598.

Al-Rawwad, T., Al-Taj, H., \& Al-Tal, S. (2016). Parental involvement and their children's social adjustment: Evidence from Jordanian students. International Review of Social Sciences and Humanities, 11(2), 119-125.

Anderson, K. J., \& Minke, K. M. (2007). Parent involvement in education: Toward an understanding of parents' decision making. The Journal of educational research, 100(5), 311-323.

Brown, A. L., Harris, M., Jacobson, A., \& Trotti, J. (2014). Parent teacher education connection: Preparing preservice teachers for family engagement. The Teacher Educator, 49(2), 133-151.

Casanova, U. (1996). Parent involvement: A call for prudence. Educational Researcher, 25(8), 30-46.

Chrispeels, J. (1996). Effective schools and home-school-community partnership roles: A framework for parent involvement. School effectiveness and school improvement, 7(4), 297-323.

DeCusati, C. L. P., \& Johnson, J. E. (2004). Parents as classroom volunteers and kindergarten students' emergent reading skills. Journal of Educational Research, 97(5), 235-246.

El Nokali, N. E., Bachman, H. J., \& Votruba-Drzal, E. (2010). Parent Involvement and Children's Academic and Social Development in Elementary School. Child Development, 81(3), 988-1005. doi:10.1111/j.1467-8624.2010.01447.x

Epstein, J. L. (1995). School/family/community partnerships: Caring for the children we share. Phi Delta Kappan, 70(3), 701-712.

Epstein, J. L., \& Jansorn, N. R. (2004). School, family and community partnerships link the plan. The Education Digest, 69(6), 19.

Epstein, J. L., \& Salinas, K. C. (2004). Partnering with families and communities. Educational leadership, 61(8), 12-19. 
Fantuzzo, J., McWayne, C., Perry, M. A., \& Childs, S. (2004). Multiple dimensions of family involvement and their relations to behavioral and learning competencies for urban, low-income children. School psychology review, 33(4), 467-480.

Fantuzzo, J., Tighe, E., McWayne, C., Davis, G., \& Childs, S. (2003). Peer-reviewed papers: parent involvement in early childhood education and children's peer-play competencies: an examination of multivariate relationships. NHSA Dialog: A Research-To-Practice Journal for the Early Intervention Field, 6(1), 3-21.

Fayez, M., Sabah, S. A., \& Rudwan, E. A. (2011). The state and level of involvement among Jordanian kindergarten parents and its relationship to teachers' efforts of outreach. Contemporary Issues in Early Childhood, 12(3), 241-251. https://doi.org/10.2304/ciec.2011.12.3.241

Frew, L. A., Zhou, Q., Duran, J., Kwok, O. M., \& Benz, M. R. (2012). Effect of school-initiated parent outreach activities on parent involvement in school events. Journal of Disability Policy Studies, 24(1), 27-35. https://doi.org/10.1177/1044207311427163

Gianzero, G. (1999). Promoting parental involvement, improving student outcomes. Unpublished manuscript. Retrieved from http://www. sandiegodialogue. org/pdfs.

Hamlin, D., \& Li, A. (2020). The relationship between parent volunteering in school and school safety in disadvantaged urban neighborhoods. Journal of School Violence, 19(3), 362-376.

Hoover-Dempsey, K. V., \& Sandler, H. M. (1997). Why do parents become involved in their children's education? Review of educational 3-42. https://doi.org/10.3102/00346543067001003

Jordan, C., Orozco, E., \& Averett, A. (2002). Emerging Issues in School, Family, \& Community Connections. Annual Synthesis, 2001.

Kaga, Y. (2007). Jordan's Strategies for Early Childhood Education in a Lifelong Learning Framework. UNESCO Policy Brief on Early Childhood. Number 39, July-August 2007. United Nations Educational, Scientific and Cultural Organization (UNESCO).

Lewis, A. E., \& Forman, T. A. (2002). Contestation or collaboration? A comparative study of home-school relations. Anthropology \& Education Quarterly, 33(1), 60-89.

Lin, Q. (2003). Parent involvement and early literacy. Harvard Family Research Project.

McWayne, C., Hampton, V., Fantuzzo, J., Cohen, H. L., \& Sekino, Y. (2004). A multivariate examination of parent involvement and the social and academic competencies of urban kindergarten children. Psychology in the Schools, 41(3), 363-377.

Murray, K. W., Finigan-Carr, N., Jones, V., Copeland-Linder, N., Haynie, D. L., \& Cheng, T. L. (2014). Barriers and facilitators to school-based parent involvement for parents of urban public middle school students. SAGE open, 4(4), 2158244014558030.

Nye, C., Turner, H., \& Schwartz, J. (2006). Approaches to Parent Involvement for Improving the Academic Performance of Elementary School Age Children. Campbell Systematic Reviews, 2(1), 1-49. doi:10.4073/csr.2006.4

Olsen, G. W., \& Fuller, M. L. (2008). Home-school relations: Working successfully with parents and families. Allyn \& Bacon.

Overstreet, S., Deine, J., Bevans, K., \&\& Efreom, Y. (2005). Predicting parental involvement in children's schooling within an economically disadvantaged African American sample. Psychology in the School, 42,101-111.

Patrikakou, E.N. \& Weissberg, R.P. (1998). Parents' Perceptions of Teacher Outreach and Parent Involvement in Children's Education. ERIC Document Reproduction Service No. ED 439800.

Smith, T. E., \& Sheridan, S. M. (2019). The effects of teacher training on teachers' family-engagement practices, attitudes, and knowledge: A meta-analysis. Journal of Educational and Psychological Consultation, 29(2), 128-157.

Sultana, R. G. (2009). Jordan's early childhood development initiative: Making Jordan fit for children.

Tokac, U., \& Kocayörük, E. (2012). Exploring Effects of Parent Involvement on Student's Achievement. International J. Soc. Sci. \& Education, 2(2), 257-263.

Topor, D. R., Keane, S. P., Shelton, T. L., \& Calkins, S. D. (2010). Parent involvement and student academic performance: A multiple mediational analysis. Journal of prevention \& intervention in the community, 38(3), 183-197.

Trotti, J., Harris, M., Jacobson, A. L., \& Brown, A. (2006).This is an authorized reprint of an article that appears online at: http://e-volunteerism. com/quarterly/06jul/fourauthors. php. May not be reproduced without permission.

Vidal de Haymes, M., O’Donoghue, S., \& Nguyen, H. (2019). The Impact of School-Based Volunteering on Social Capital and Self-and Collective Efficacy among Low-Income Mothers. Children \& Schools, 41(2), 79-88. 